\title{
Chromatographic evaluation and antimicrobial activity of Neem (Azadirachta indica A. Juss., Meliaceae) leaves hydroalcoholic extracts
}

\author{
Priscila D. Alves, Maria G. L. Brandão, Elzíria A. Nunan, Cristina D. Vianna-Soares* \\ Departamento de Produtos Farmacêuticos, Universidade Federal de Minas Gerais, Av. Pres. Antônio Carlos \\ 6627, 31270-901 Belo Horizonte-MG, Brazil
}

\begin{abstract}
RESUMO: "Avaliação cromatográfica e atividade antimicrobiana de extratos hidroalcoólicos de folhas de Nim (Azadirachta indica A. Juss., Meliaceae)". O Nim (Azadirachta indica A. Juss., Meliaceae) é uma árvore indiana conhecida por suas várias atividades farmacológicas, entre elas, a ação antimicrobiana. Dentre mais de 300 compostos já isolados, a azadiractina (AZA) é seu principal componente ativo. No presente trabalho, foram preparados extratos hidroalcoólicos de folhas de Nim em diferentes concentrações de etanol 96\% V/V (50\%, 60\%, 70\%, 80\% e 90\% $(\mathrm{V} / \mathrm{V}))$ por meio de percolação estática. A presença de AZA foi verificada por CCD, com eluição dos extratos e da solução padrão de trabalho AZA em cromatoplaca e revelação por solução de anisaldeído/ácido sulfúrico, seguida de aquecimento. Por CLAE, os extratos e da solução padrão de trabalho AZA foram eluídos em coluna C18, fase móvel água:acetonitrila (60:40), fluxo 1,0 mL/ min e detecção em $\lambda_{217} \mathrm{~nm}$. Não foi verificada a presença de manchas ou picos correspondentes a AZA nos extratos. Entretanto, a sua atividade foi investigada contra bactérias Gram-positivas, Gram-negativas, leveduras e um fungo filamentoso. Os extratos foram testados em diferentes concentrações para avaliar a relação dose-resposta. Apesar da ausência de AZA, os extratos hidroalcoólicos a 70\% e $80 \%(\mathrm{~V} / \mathrm{V})$ de etanol $96 \%$ apresentaram atividade contra Staphylococcus aureus. Porém, não houve relação dose-efeito, de acordo com o teste de Tukey $\left(\mathrm{q}_{0,05 ; 3 ; 7}\right)$.
\end{abstract}

Unitermos: Azadirachta indica, nim, CLAE, atividade antimicrobiana, extrato hidroalcoólico.

\begin{abstract}
Chromatographic evaluation and antimicrobial activity of Neem (Azadirachta indica A. Juss., Meliaceae) leaves hydroalcoholic extracts". Neem (Azadirachta indica) is an Indian tree well known for its several pharmacological activities, including antimicrobial activity. More than 300 composites have already been isolated and azadirachtin (AZA) is its main active component. In the present work, Neem leaves hydroalcoholic extracts were prepared by percolation in $96 \%$ ethanol different concentrations $(50 \%, 60 \%, 70 \%, 80 \%$ and $90 \%(\mathrm{v} / \mathrm{v}))$. The presence of AZA was tested by TLC by eluting the extracts and a standard solution of AZA through a chromatographic plate developed with anisaldehyde/sulfuric acid solution followed by heating. By HPLC, extracts elution took place on a C18 column, water:acetonitrile (60:40) as mobile phase, $1.0 \mathrm{~mL} / \mathrm{min}$ flow rate and detection at $\lambda_{217} \mathrm{~nm}$ The extracts did not display AZA spots or peaks, however, they were tested against Gram-positive and Gram-negative bacteria, yeasts and a mold fungus. The extracts were tested in different increasing concentrations, in order to detect a dosedependent relationship of the activity. Despite the absence of AZA, the $70 \%$ and $80 \%(\mathrm{v} / \mathrm{v})$ ethanol extracts showed activity against Staphylococcus aureus. However, this activity was not dosedependent according to Tukey's test $\left(\mathrm{q}_{0,05 ; 3 ;}\right)$.
\end{abstract}

Keywords: Azadirachta indica, neem, HPLC, antimicrobial activity, hydroalcoholic extract.

\section{INTRODUCTION}

Neem (Azadirachta indica A. Juss.) is a tree from the Meliaceae family originated from India. It is known for its pesticide activity against more than 400 insect pests (Siddiqui et al., 2003) and pharmacological activities, such as anti-inflammatory, anti-malaria, anti-fertility, antimicrobial (Subapirya \& Nagini, 2005; Dai et al., 1999), anti-acne (Jain \& Basal, 2003), acaricidal (Abdel-Shafy \& Zayed, 2002), and nematicidal (Sharma et al., 2003). The plant is traditionally used in the Indian region and many of its activities have been studied.

Azadirachtin (AZA, 1), the main active component of this plant, is a tetranortriterpenoid abundant in the seeds and present in a smaller concentration in the leaves. Other active substances are salanin, 14- 
epoxiazadiradione, meliantrol, melianone, gedunin, nimboline, nimbin, deacetilasalanin, azadiractol, azadirone, vilosinin, meliacarpine, over 300 isolated and characterized components (Dai et al., 1999; Sharma et al., 2003; Silva, 2005). In their terpene common chemical structure functional groups such as, acetate, hydroxyl and esters can be linked. The main active component, AZA, is commonly used as the biological marker for this plant.

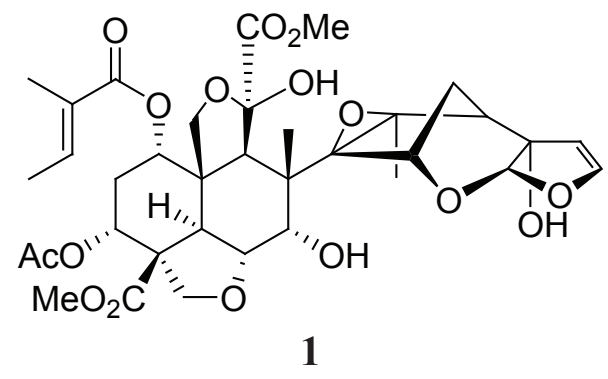

There are several studies on the antimicrobial activity of Neem. Some of them have demonstrated activities of extracts from seeds and leaves against Staphylococcus aureus, Escherichia coli, as well as, negative results against Bacillus subtillis, S. paratyphi, S. desynteriae and Candida albicans (Alhmad \& Beg, 2001). Neem leaves are efficient against pathogenic fungi, such as Trichophyton, Epidermophyton, Microsporum, Trichosporon and Geotricum (Khan \& Wassilew, 1987). The activity in inhibiting the protease of Trichophyton (Iyer \& Williamson, 1991), the production of aflatoxin of A. parasiticus (Allamed et al., 2001), antifeedant activity (Silva et al., 2007) and the antifungal activity against Penicillium expansum (Mossini et al., 2004) have been confirmed. The Neem seed oil also showed a wide spectrum activity against Gram-negative and Grampositive microorganisms, including $M$. tuberculosis and streptomicine resistant strains (Chopra et al., 1952). The leaves also inhibited the growth of Vibrio cholerae, Klebsiella pneumoniae, M. tuberculosis and M. pyogenes in vitro (Satyavati et al., 1976).

In this work, we described the antimicrobial activity of Neem hydroalcoholic leaves extracts against Gram-positive and Gram-negative bacteria, yeasts and a mold fungus.

\section{MATERIAL AND METHODS}

\section{Plant material and extracts}

Neem leaves were collected from a commercial crop in the town of Pompéu (Latitud -18 56'24' South, Longitud $-45^{\circ} 6^{\prime} 0^{\prime \prime}$ West), Minas Gerais state (Brazil). The extracts were prepared by percolation of $500 \mathrm{~g}$ of crushed Neem leaves in $500 \mathrm{~mL}$ of $96 \%$ ethanol at $50 \%, 60 \%$, $70 \%, 80 \%$ e $90 \%$ (v/v), in triplicate. The leaves, previously moistened with adequate solvent, were transferred to a percolator, wherein were completely covered by solvent.
After standing for $48 \mathrm{~h}$ the first fraction was collected. Additional solvent was poured, standing for further 24 $\mathrm{h}$, when the second fraction was collected. This process was repeated until $500 \mathrm{~mL}$ of the extract for each of the different hydroalcoholic concentration were obtained. An aliquot of $125 \mathrm{~mL}$ of each extract was dried in a rotatory evaporator to obtain a residue, which was dried in a vacuum oven at $40{ }^{\circ} \mathrm{C}$ for $6 \mathrm{~h}$ and left in a desiccator for $50 \mathrm{~h}$. An amount of $100 \mathrm{mg}$ of the residue was accurately weighed and reconstituted in $1.0 \mathrm{~mL}$ of ethanol $50 \%(\mathrm{v} / \mathrm{v})$. The latter solvent was used as blank. The same procedure was repeatedly performed with different residue amounts to prepare extract concentrations at $150,200,250$ or 300 $\mathrm{mg} / \mathrm{mL}$.

\section{Chromatographic evaluation}

\section{Thin layer chromatography}

The extracts were tested by thin-layer chromatography (TLC). The elution system was a mixture of methylene chloride:methanol (99:1). Samples of the hydroalcoholic extracts and $1.0 \mathrm{mg} / \mathrm{mL}$ AZA standard (Chemservice, West Chester, PA, USA, technical grade) in methylene chloride were applied to the chromatographic plate (silica gel $60 \mathrm{~F}_{254}$, Merck, Darmstadt, Germany), using glass capillary tubes and eluted. The plate was developed using anysaldehyde/sulfuric acid solution followed by heating.

\section{High performance liquid chromatography}

The neem hydroalcoholic extracts at $70 \%$ and $80 \%(\mathrm{v} / \mathrm{v})$ were tested by reverse phase-high performance liquid chromatography (HPLC). The analyses were performed on an HP1100 series chromatograph (Agilent, Palo Alto, CA, USA) equipped with a quaternary pump, automatic injector and an ultraviolet diode array detector (UV/DAD) module. Separation was accomplished on a C18 column (Agilent, $250 \times 4.6 \mathrm{~mm}$ ) oven set at 30 ${ }^{\circ} \mathrm{C}$ (CH-500, Eppendorf, Madison, WI, USA). Internal ChemStation software version 07.01 was used for data acquisition. Mobile phase water:acetonitrile (60:40) at $1.0 \mathrm{~mL} / \mathrm{min}$ flow rate, $20 \mu \mathrm{L}$ injection volume, and $\mathrm{UV}$ detection at $\lambda_{217} \mathrm{~nm}$ were used.

\section{Antimicrobial evaluation}

\section{Microorganisms and media}

The standard microorganisms cultures Bacillus subtilis (ATCC 6633), Micrococcus luteus (ATCC 9341), Staphylococcus aureus (ATCC 6538p), Escherichia coli (ATCC 8739), Pseudomonas aeruginosa (ATCC 9027), Salmonella thiphymurium (ATCC14028), Saccharomyces cerevisae (ATCC 2601), Candida albicans (ATCC 
10231), Candida tropicalis (ATCC 1641) were used. The microorganisms were grown in nutrient agar (Biobras, Montes Claros, MG, Brazil) and Sabouraud-dextrose agar (Difco, Franklin Lakes, NJ, USA), for bacteria and fungi, respectively.

\section{Antibiotic standards}

Chloramphenicol, reference standard (Sigma, Saint Louis, MO, USA), was used as positive control, for bacteria tests, except for Pseudomonas aeruginosa, for which gentamicin reference standard (Sigma, Saint Louis, MO, USA) was used. Amphotericin B (Fungison ${ }^{\circledR}$, Bristol, New York, NY, USA) was used in the tests for yeasts and mold fungus.

\section{In vitro antimicrobial activity evaluation}

The antimicrobial activity of the hydroalcoholic extracts was determined by means of the disc diffusion method (Nunan et al., 1985; NCCLS, 1993). The inoculum was standardized by transferring colonies from the nutrient agar or Saboraud-dextrose agar to sterile saline up to $10^{8}$ $\mathrm{cfu} / \mathrm{ml}$, equivalent to $60 \% \pm 1 \%$ transmittance at $\lambda_{580} \mathrm{~nm}$ (Junior II 6/20 Coleman spectrophotometer, Maywood, IL, USA). This suspension was ten-fold diluted in saline (1 $\mathrm{mL}$ of suspension and $9 \mathrm{ml}$ of saline). An aliquot of $250 \mu \mathrm{L}$ was withdrawn from the diluted suspension and transferred to an Erlenmeyer flask with $50 \mathrm{~mL}$ of the appropriate agar for each microorganism to obtain a $0.05 \%(\mathrm{v} / \mathrm{v})$ inocula. For Bacillus subtilis and Aspergillus niger cultures, a 0.1\% (v/v) Tween 80 (Synth, São Paulo, SP, Brazil) solution was added.

The agar was composed of a bilayer, either casein soy agar or Sabouraud-dextrose agar $(20 \mathrm{~mL})$, was poured into Petri dishes $(100 \times 20 \mathrm{~mm})$ to form the base layer. After solidification of this layer, portions of $5 \mathrm{~mL}$ of inoculated casein soy agar or Sabouraud-dextrose agar were poured over the base layer.

The extracts were initially tested at $100 \mathrm{mg} / \mathrm{mL}$, in triplicate. Six discs (6.0 mm i.d.) were impregnated with $20 \mu \mathrm{L}$ of the extracts and placed on the surface of the agar containing each microorganism, which was incubated at $36.0 \pm 1.0^{\circ} \mathrm{C}$ for $24 \mathrm{~h}$ and at $22-25^{\circ} \mathrm{C}$ for $48 \mathrm{~h}$ for bacteria and fungus, respectively. The inhibition zones were measured with a caliper considering the total diameters. Similarly, each plate carried a blank disc containing 20 $\mu \mathrm{L}$ of ethanol $50 \%(\mathrm{v} / \mathrm{v})$ and a control antibiotic disc containing $20 \mu \mathrm{g}$ of chloramphenicol $(1.0 \mathrm{mg} / \mathrm{mL})$ or gentamicine $(1.0 \mathrm{mg} / \mathrm{mL})$ and $40 \mu \mathrm{g}$ amphotericin B $(2.0$ $\mathrm{mg} / \mathrm{mL}$ ), for bacteria and fungi, respectively.

The assay was repeated $(\mathrm{n}=3)$ for those extract solution impregnated disks which showed any microorganism growth inhibition. Concentrations of 100 $\mathrm{mg} / \mathrm{mL}, 150 \mathrm{mg} / \mathrm{mL}, 200 \mathrm{mg} / \mathrm{mL}, 250 \mathrm{mg} / \mathrm{mL}$ and 300 $\mathrm{mg} / \mathrm{mL}$ were used. The results were submitted to analysis of variance and the means were compared by Tukey test $\left(\mathrm{q}_{0,05 ; 3 ; 7}\right)$, using Microsoft Excel ${ }^{\circledR} 2002$.

\section{RESULTS AND DISCUSSION}

The extracts evaluated by TLC, presented several spots developed. It is noteworthy that no AZA correspondent spot was present in the Neem extracts. Other spots present possibly correspond to other active substances. The hydroalcoholic extracts have also been tested by HPLC and compared to AZA reference solution $(0.4 \mathrm{mg} / \mathrm{mL})$. The AZA reference solution chromatogram is represented in Figure 1. Two elution peaks can be observed, at $7.933 \mathrm{~min}$ and $8.780 \mathrm{~min}$ with the same spectrophotometric profile, represented in Figure 1. In order to verify whether peak splitting was dependent on $\mathrm{pH}, 1 \%(\mathrm{v} / \mathrm{v})$ triethanolamine or $1 \%(\mathrm{v} / \mathrm{v})$ trifluoroacetic acid in water solutions were prepared and used in the mobile phase. However, there were no differences in the chromatograms by this $\mathrm{pH}$ alteration, indicating that the peaks corresponded to distinct substances. Therefore, the peaks at $7.933 \mathrm{~min}$ and $8.780 \mathrm{~min}$ were considered to be AZA peaks. A representative chromatogram for the extracts eluted by HPLC is represented in Figure 2. As it is evidenced in the chromatogram, there were no AZA peaks at circa of 7.9 and $8.7 \mathrm{~min}$. It is possible to assert that the extracts do not have AZA in a quantifiable amount, indicating its absence in the hydroalcoholic extracts tested. The other peaks present may correspond to other substances in Neem (Subapriya \& Nagini, 2005; Martinez, 2002; Siddiqui et al., 2003; Silva, 2005).

The extracts prepared with different ethanolic concentrations were tested against pathogenic microorganisms for determining any antimicrobial activity by the diffusion disk method. The growth inhibition zones measured (in $\mathrm{mm}$ ) for the positive antibiotic control used were: chloramphenicol (1.0 mg/mL), $29.5 \pm 1.8$ against $B$. subtilis, $31.8 \pm 0.3$ against $M$. luteus, $26.0 \pm 0.8$ against $S$. aureus, $19.5 \pm 0.3$ against $E$. coli and $19.3 \pm 0.3$ against $S$. thiphymurium; gentamicin $(1.0 \mathrm{mg} / \mathrm{mL}), 10.0 \pm 0.1$ against $P$. aeruginosa. Amphotericin $\mathrm{B}, 12.7 \pm 0.3$ against $S$. cerevisae, $28.3 \pm 0.5$ against $C$. albicans and $24.0 \pm$ 0.8 against $C$. tropicalis. Blank control did not show any inhibition zone. The hydroalcoholic extracts at 50\%, 60\% and $90 \%(\mathrm{v} / \mathrm{v})$ did not show any antimicrobial activity at the tested concentration $(100 \mathrm{mg} / \mathrm{mL})$. The extracts obtained at $70 \%$ and $80 \%(\mathrm{v} / \mathrm{v})$ ethanol, however, did show activity against Staphylococcus aureus. However, it was not possible to measure the diameter of the growth inhibition zone, precisely, which featured a local inhibition. The active extracts were tested in different increasing concentrations, in order to determine a possible dose-dependent activity against $S$. aureus. As shown in Table 1, the extracts still showed little activity, verified by measuring the local growth inhibition zone. In Table 2 , the results presented show that the variance in the growth 
inhibition zones were not statistically significant (Tukey test, $\left.\mathrm{q}_{0.05 ; 3 ;}\right)$, therefore, there was no relationship between the applied dosage and the extract antimicrobial activity.

Although the antimicrobial activity of the Neem leaves extract against several microorganisms has been described by several authors (Almad \& Beg, 2001; Chopra et al., 1952; Subapirya \& Nagini, 2005), the same was not verified for the hydroalcoholic extracts tested from the neem grown in Minas Gerais state, Brazil. The absence of AZA, as shown by HPLC chromatogram (Figure 3) and observed by TLC, may justify the little antimicrobial activity of the Neem leaves hydroalcoholic extracts. A possible cause for the absence of those substances may be the crops environmental conditions (climate, soil), in case the tree may not have adjusted well to the climate and soil in Minas Gerais. It is known that there is a great difference in the extracts composition of plants cultivated in different locations. The adaptation to the field and soil composition is an important factor for the proper active ingredient production in the plants, according to Sidhu et al. (2003).

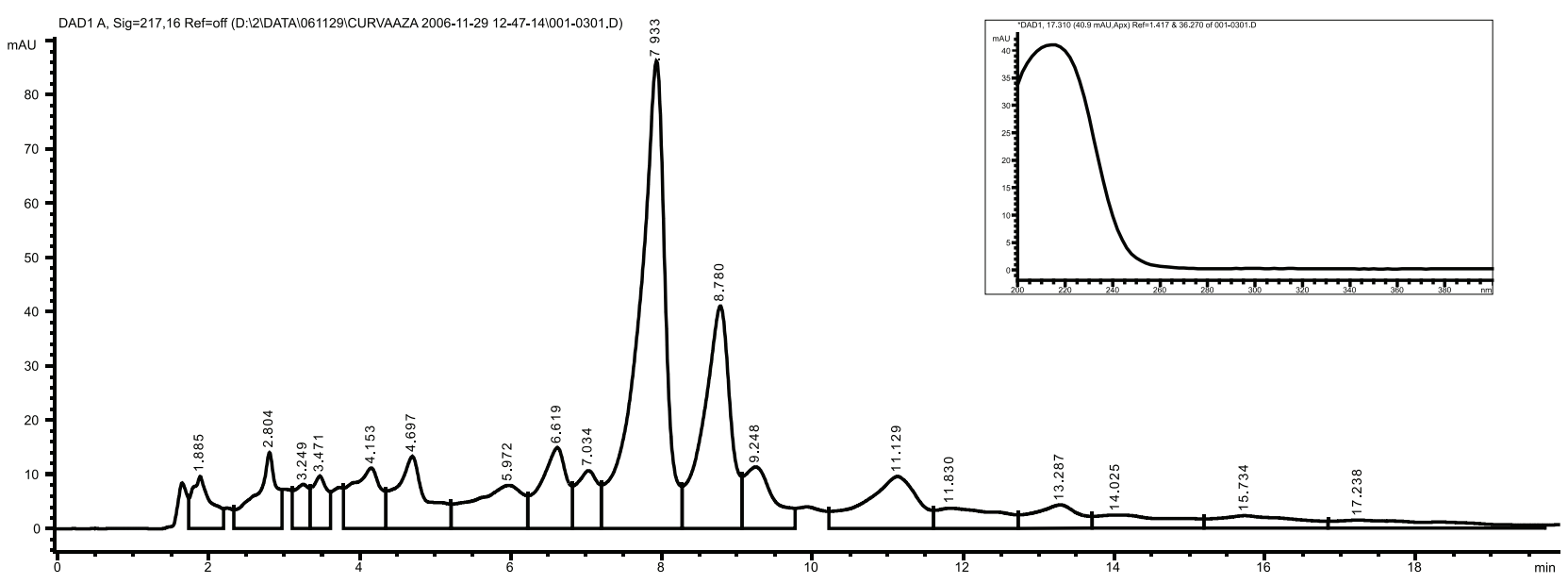

Figure 1. Representative chromatogram of AZA reference solution $(0.4 \mathrm{mg} / \mathrm{mL})$ tested by HPLC-UV/DAD, mobile phase Figure 2 . Representative chromatogram of AZA reference solution $(0.4 \mathrm{mg} / \mathrm{mL})$ tested by HPLC-UV/DAD, mobile phase water:acetonitrile (60:40), C18 column, $20 \mu \mathrm{L}$ injection volume, $\lambda_{217} \mathrm{~nm}$ detection, peaks at 7.933 and $8.780 \mathrm{~min}$. Insert: UV/DAD spectrum for AZA reference solution peaks.

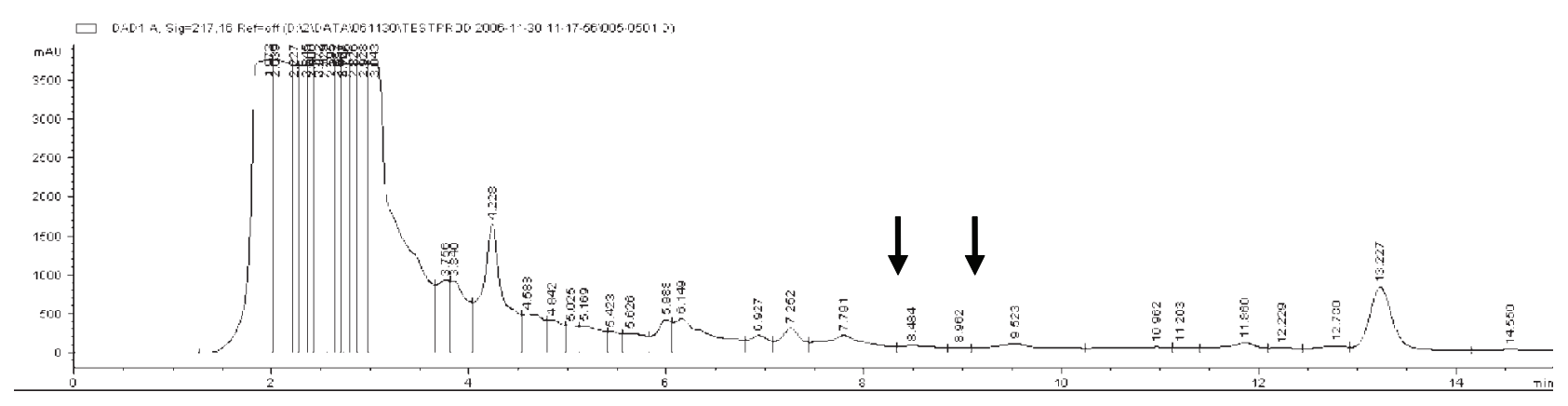

Figura 2. Representative chromatogram of the hydroalcoholic extract at $70 \% \mathrm{v} / \mathrm{v}$ ethanol tested by HPLC, mobile phase water:acetonitrile (60:40), C18 column, $20 \mu \mathrm{L}$ injection volume, $\lambda_{217} \mathrm{~nm}$ detection. Arrows show the expected retention times for AZA peaks at circa of 7.9 and $8.7 \mathrm{~min}$. 
Table 1. Influence of different concentrations of neem leaves hydroalcoholic extracts at $70 \%$ and $80 \%$ (v/v) ethanol on $S$. aureus growth by disc plate dilution method.

\begin{tabular}{|c|c|c|c|c|c|c|}
\hline \multirow{3}{*}{$\begin{array}{l}\text { Positive control } \\
\text { (chloramphenicol) }\end{array}$} & \multirow{3}{*}{$\begin{array}{c}\begin{array}{c}\text { Concentration } \\
(\mathrm{mg} / \mathrm{mL})\end{array} \\
1.0\end{array}$} & & \multicolumn{3}{|c|}{$\begin{array}{l}\text { Inhibition zone } \pm \mathrm{SD}^{\mathrm{a}} \\
\qquad(\mathrm{mm})\end{array}$} & \multirow{3}{*}{$\begin{array}{c}\begin{array}{c}\text { Mean zone } \pm \mathrm{SD}^{\mathrm{a}} \\
(\mathrm{mm})\end{array} \\
23.80^{\mathrm{b}} \pm 0.4\end{array}$} \\
\hline & & & & & $24.00 \pm 0.1$ & \\
\hline & & & $22.65 \pm 0.8$ & $24.20 \pm 0.3$ & $24.40 \pm 0.4$ & \\
\hline \multirow{10}{*}{$\begin{array}{l}\text { Hydroalcoholic Neem } \\
\text { leaves extracts }\end{array}$} & \multirow{2}{*}{100} & $70 \%$ & $7.00 \pm 0.1$ & $6.95 \pm 0.1$ & $6.85 \pm 0.1$ & $6.93^{c} \pm 0.1$ \\
\hline & & $80 \%$ & $6.60 \pm 0.0$ & $6.50 \pm 0.1$ & $6.70 \pm 0.1$ & $6.60 \pm 0.1$ \\
\hline & \multirow{2}{*}{150} & $70 \%$ & $6.70 \pm 0.2$ & $7.35 \pm 0.2$ & $7.05 \pm 0,1$ & $7.03 \pm 0.2$ \\
\hline & & $80 \%$ & $7.10 \pm 0.2$ & $6.60 \pm 0.2$ & $6.75 \pm 0.1$ & $6.82 \pm 0.1$ \\
\hline & \multirow{2}{*}{200} & $70 \%$ & $7.30 \pm 0.1$ & $7.50 \pm 0.1$ & $7.55 \pm 0.1$ & $7.45 \pm 0.1$ \\
\hline & & $80 \%$ & $6.10 \pm 0.1$ & $6.35 \pm 0.1$ & $6.20 \pm 0.1$ & $6.22 \pm 0.1$ \\
\hline & \multirow{2}{*}{250} & $70 \%$ & $7.20 \pm 0.3$ & $7.45 \pm 0.1$ & $8.10 \pm 0.4$ & $7.58 \pm 0.2$ \\
\hline & & $80 \%$ & $6.65 \pm 0.2$ & $7.15 \pm 0.3$ & $7.10 \pm 0.1$ & $6.97 \pm 0.2$ \\
\hline & \multirow{2}{*}{300} & $70 \%$ & $7.50 \pm 0.3$ & $7.25 \pm 0.1$ & $7.20 \pm 0.1$ & $7.32 \pm 0.1$ \\
\hline & & $80 \%$ & $6.45 \pm 0.4$ & $8.00 \pm 0.5$ & $6.35 \pm 0.4$ & $6.93 \pm 0.5$ \\
\hline
\end{tabular}

a: standard deviation, $\mathrm{b}: \mathrm{n}=6$ for standard, $\mathrm{c}: \mathrm{n}=3$ for extracts.

Table 2. Statistic results for Tukey's test ${ }^{\mathrm{a}}$ in order to verify the dose-response relationship for the hydroalcoholic Neem leaves extracts at $70 \%$ and $80 \%(\mathrm{v} / \mathrm{v})$ ethanol against $S$. aureus.

\begin{tabular}{|c|c|c|c|c|c|c|}
\hline \multicolumn{7}{|c|}{ Hydroalcoholic extract at $70 \%(\mathrm{v} / \mathrm{v})^{\mathrm{b}}$} \\
\hline $\begin{array}{l}\text { Concentration } \\
(\mathrm{mg} / \mathrm{mL})\end{array}$ & Mean & 250 & 200 & 300 & 150 & Discrimination \\
\hline 250 & 7.58 & - & - & - & - & $\mathrm{a}$ \\
\hline 200 & 7.45 & 0.13 & - & - & - & $\mathrm{a}$ \\
\hline 300 & 7.32 & 0.27 & 0.13 & - & - & a \\
\hline 150 & 7.03 & 0.55 & 0.42 & 0.28 & - & $\mathrm{a}$ \\
\hline 100 & 6.93 & 0.65 & 0.52 & 0.38 & 0.10 & a \\
\hline \multicolumn{7}{|c|}{ Hydroalcoholic extract at $80 \%(\mathrm{v} / \mathrm{v})^{\mathrm{c}}$} \\
\hline $\begin{array}{l}\text { Concentration } \\
(\mathrm{mg} / \mathrm{mL})\end{array}$ & Mean & 250 & 300 & 150 & 100 & Discrimination \\
\hline 250 & 6.97 & - & - & - & - & $\mathrm{a}$ \\
\hline 300 & 6.93 & 0.03 & - & - & - & a \\
\hline 150 & 6.82 & 0.15 & 0.12 & - & - & a \\
\hline 100 & 6.60 & 0.37 & 0.33 & 0.22 & - & a \\
\hline 200 & 6.22 & 0.75 & 0.72 & 0.60 & 0.38 & $\mathrm{a}$ \\
\hline
\end{tabular}

a: critical $\mathrm{q}_{0.05 ; 3 ; 7}=4.17$, obtained from Tukey's table, considering 3 different treatments (replicates) and 7 degrees of freedom, $\mathrm{b}$ : minimum significative difference $(\mathrm{MSD})=1.39$; $\mathrm{MSD}=11.08$.

\section{CONCLUSION}

The tests performed on the Neem leaves hydroalcoholic extracts originated from such crop in Minas Gerais indicate that those leaves did not yield enough AZA for detection by TLC or HPLC-UV/DAD, hence the extracts activity against microorganisms was limited. The reasons for this may be due to crop location, plants young age or soil condition. Although AZA could not be detected in the Neem leaves extracts, antimicrobial activity detected against $S$. aureus may be due to the presence of several substances, other than AZA, indicating that the leaves extract can be used against this bacterium, a very important pathogenic microorganism. 


\section{ACKNOWLEDGEMENTS}

The authors thank to Memovip Ltda. for financial support and providing the neem leaves.

\section{REFERENCES}

Abdel-Shafy S, Zayed AA 2002. In vitro acaricidal effect of plant extract of neem seed oil (Azadirachta indica) on egg, immature, and adult stages of Hyalomma anatolicum excavatum (Ixodoidea : Ixodidae). Vet Parasitol 106: 8996.

Allamed A, Abyameh MR, Shams M, Rezaee MB, Jaimand K 2001. Effects of neem leaf extract on production of aflatoxins and activities of fatty acid synthetase, isocitrate dehydrogenase and glutathione S-transferase in Aspergillus parasiticus. Mycopathologica 154: 79-84.

Almad I, Beg AZ 2001. Antimicrobial and phytochemical studies on 45 medicinal plants against multi-drug resistant human pathogens. J Ethnopharmacol 74: 113-123.

Chopra IC, Gupta KC, Nazir BN 1952. Preliminary study of antibacterial substances from Melia azidirachta. Indian $J$ Med Res 40: 511-515.

Dai J, Yaylayan VA, Raghavan GSV, Paré JR 1999. Extraction and colorimetric determination of azadirachtin-related limonoids in neem seed kernel. J Agric Food Chem 47: 3738-3742.

Iyer, SR, Williamson, D 1991. Efficacy of some plant extracts to inhibit the protease activity of Trichophyton species. Geobios 18: 3-6.

Jain A, Basal E 2003. Inhibition of propionibacterium acnesinduced mediators of inflammation by Indian herbs. Phytomedicine 10: 34-38.

Khan M, Wassilew SW 1987. Natural pesticides from the neem tree and other tropical plants. Eschborn, Alemanha: GTZ, apud $O$ Nim. Azadirachta indica, natureza, usos múltiplos, 2002.

Martinez SS 2002. O Nim. Azadirachta indica, natureza, usos múltiplos. Londrina, Paraná: Instituto Agronômico do Paraná.

Mossini SA, De Oliveira KP, Kemelmeier C 2004. Inhibition of patulin production by Penicillium expansum cultured with neem (Azadirachta indica) leaf extracts. $J$ Basic Microbiol 44: 106-113.

NCCLS 1993. National Committee for Clinical Laboratory Standards Performance standards for antimicrobial disk susceptibility test, approved standard. M2-A5.

Nunan EA, Campos LMM, Paiva RLR, Oliveira ST, Daudoun HA, Oliveira AB 1985. Estudo da atividade antimicrobiana de extrato de folha de Aristolochia gigantea Mart. Zucc. Rev Farm Bioquim 6: 33-40.

Satyavati GV, Raina MK, Sharma M 1976. Medicinal plants of India. New Delhi, Índia Indian Council Med. Res. 1. apud Subapirya R, Nagini S 2005. Medicinal properties of Neem leaves: a review. Curr Med Chem Anticancer Agents 5: 149-156.

Sharma V, Walia S, Kumar J, Nair MG, Parmar BS 2003. An efficient method for the purification and characterization of nematicidal azadirachtins A, B and H, using MPLC and ESIMS. J Agric Food Chem 51: 3966-3972.

Siddiqui BS, Afshan F, Gulzar T, Sultana R, Naqvi SN, Tariq RM 2003. Tetracyclic triterpenoids from the leaves of
Azadirachta indica and their insecticidal activities. Chem Pharm Bull 51: 415-417.

Sidhu OP, Kumar V, Behl HM 2003. Variability in neem (Azadirachta indica) with respect to azadirachtin content. J Agric Food Chem 51: 910-915.

Silva JCT 2005. Tetranortriterpenoid isolation from Azadirachta indica (neem) seeds and evaluation of nematicide activity over Heterodera glycines. Viçosa, Minas Gerais, Brazil. 81 p. Agrochemistry Master Science Thesis - Department of Chemistry, Federal University of Viçosa.

Silva JP, Crotti AEM, Cunha WR 2007. Antifeedant and allelopathic activities of the hydroalcoholic extract obtained from Neem (Azadirachta indica) leaves. Rev Bras Farmacogn 17: 529-532.

Subapirya R, Nagini S 2005. Medicinal properties of Neem leaves: a review. Curr Med Chem Anticancer Agents 5: 149-156. 